\title{
National Banking Areas in Dynamics: Evidence from the USA and Russia, 1980s - 2015
}

\author{
Leonid V. Nikitin* \\ Chelyabinsk State Pedagogical University \\ 69 Lenin, Chelyabinsk, 454080, Russia
}

Received 16.04.2015, received in revised form 14.05.2015, accepted 10.09.2015

\begin{abstract}
Like many other sectors of economy, banking industry is unevenly distributed across countries and cities. At the same time banking is notable for availability of large statistical databases that can be arranged and treated for aims of geographical and historical study. The author investigates two important cases of competition between cities: inner banking areas of the United States and Russian Federation. Quantitative analysis, embracing series of macroeconomic cycles, shows both similarities and dissimilarities between these counties.
\end{abstract}

Keywords: cities, banks, competition, USA, Russia, neoliberal economy of the 1980s-2010s.

DOI: 10.17516/1997-1370-2015-8-11-2545-2553.

Research area: history, economics.

While history of global financial centres is a subject of rather long-standing and intensive interest among scholars, until now there have been few analogous publications focused on national-level competitions between cities in this industry. However, examining this tier of inter-city relations we can see many important regularities and tendencies: sometimes unique, sometimes common for numerous countries, and, in any case, making a 'grassroots' basis for global financial metropolises.

In this paper author depicts two important samples of national banking geographies: that of the USA and Russian Federation'. The United States are interesting for durable and competitive evolution of banking business, although tightly regulated since the 1930s. On the other hand,
Russia is notable because of its different and very dramatic history: there non-government banking activities were twice interrupted by periods of total state monopoly in the financial service (during 1917-1921 and 1930-1987).

But in spite of all previous dissimilarities, in the 1980s both countries started their transitions to neoliberal economy and free-market banking. So, we can trace some further parallels, including those in spatial organization of credit sector. Such investigation seems even more appropriate since there are other common features between the USA and Russia, like federal arrangements and great inner diversities. Besides, these countries are not too different in their area and population numbers. Moreover, there are large-scale and detailed databases (although demanding many

(C) Siberian Federal University. All rights reserved

* Corresponding author E-mail address: lnd2001nikitin@mail.ru 
additional calculations), provided by the U.S. Federal Deposit Insurance Corporation (FDIC) [Federal Deposit...], Federal Reserve Archival System for Economic Research (FRASER) [Federal Reserve...] and the Central Bank of Russian Federation (TsBRF) [Tsentral'nyi...]. These and some other sources enable us to monitor developments during three neoliberal decades and three successive business cycles in global economy, namely: (i) the recession of 1980-1982 and growth during 1983-1989, (ii) the recession of 1990-1992 and growth during 1993-2000, (iii) the recession of 2001 and growth during 20022007. Besides, now we can touch upon the fourth cycle, which was started by the recent crisis of 2008-2009 and is not yet completed. Finally, after this chronologically arranged study, it is possible to look at some contemporary characteristics, including presence of foreign credit corporations in both countries.

So, by the beginning of the first period (19801989) the U.S. banking service had been strictly regulated by laws and government institutions. For geographical parameters of the industry, the McFadden - Pepper Act of 1927 was the most important factor. Codifying and reinforcing the old American tradition, this Act prohibited interstate branching. Although in later decades some new mechanisms (deposit certificates, ATM networks, etc.) helped to compensate this ban to a certain extent, the U.S. banking area was deeply fragmented. Several other restrictions were in practice since the Great Depression and New Deal of the 1930s. Much later, inflation waves of the 1970s and increasing ineffectiveness of Keynesian-style regulation caused the abovementioned transition to neoliberal economy. In the sphere of banking there were three key documents (the Depository Institutions Deregulation and Monetary Control Act of 1980, the Garn - St. Germain Depositary Institutions Act of 1982 and a while later the Competitive Equality Banking
Act of 1987), which allowed, for example, some kinds of inter-state mergers.

Earlier, banking space of the USA was quite even and predictable. Looking at the level of states we can see high statistical correlations between population numbers and assets of local banking corporations. Among cities, for decades there was predominance of New York, followed by San Francisco, Chicago and Los Angeles.

New rules led to important changes. Now this or that corporation (depending on its financial fundament and ambitions of shareholders and top-managers, but still relying upon permission from federal regulators) could acquire smaller and half-bankrupted institutions in various parts of the country. Although limited, this innovation enabled some banks and banking holdings to grow considerably. As a result, in several cities summarized banking assets of local corporations have grown too. At that period, the clearest examples were Charlotte in North Carolina, Atlanta in Georgia, Birmingham in Alabama, as well as Houston and Dallas in Texas. Besides, there was one more phenomenon: a kind of "domestic off-shores", i.e. some states that adopted tax and other facilities into their legislations. Consequently, such jurisdictions (mainly Delaware, South Dakota and Nevada) have attracted card-issuing subsidiaries of the largest banking holdings of the USA.

So, at the mid-1980s banking map of the country was noticeably different from that of previous decades. Some cities and territories became stronger; many others faced decreasing of their assets. In general, scale of changes can be measured by one of basic statistical instruments, namely standard deviation (SD). In terms of this study, growth of SDs means that gaps between successful and unsuccessful cities become larger (and vice versa). Measuring annual SDs for big group of cities, we can easily conclude that the first half and middle of the 1980s was the period of 


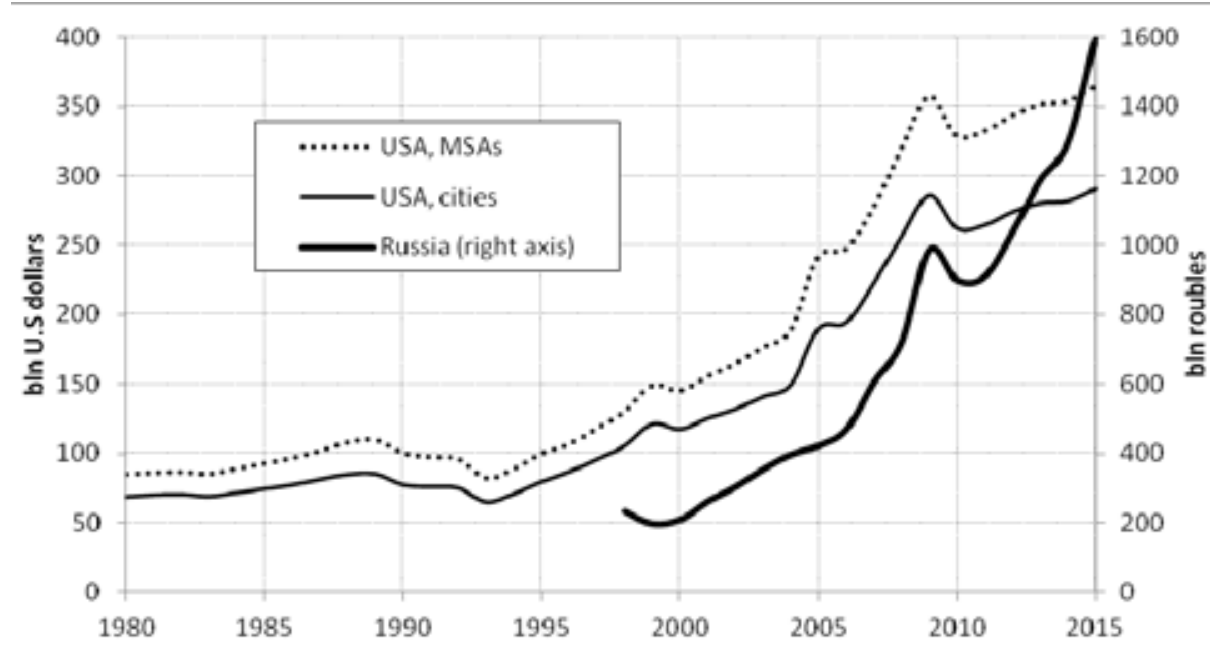

Fig. 1. Summarized banking assets by 200 U.S. cities (131 MSAs ${ }^{3}$ ) and 200 Russian cities: Annual standard deviations, 1980-2015 (national currencies; 2005 deflators).Calculations based on data from FDIC, FRASER, OMB, TsBRF and UNSD

somewhat increasing geographical stratification (Fig. 1) ${ }^{2}$.

However, after 1986 the situation changed dramatically. It became clear that many credit corporations were not ready to work in more liberal conditions. Too risky market strategies led to unprecedented wave of bankruptcies. In some regions the situation was even harder because of falling prices in their staple industries: in oil and gas energy (especially in Texas and Oklahoma) and agriculture (in the Midwest and again in Texas). During the rest of the decade the U.S. banking sector was in crisis ${ }^{4}$. Later, at the eve of the 1990s, this crisis played its role in provoking general economic recession.

Such circumstances caused further changes in banking geography. Some of the cities that showed especially high growth rates in previous years now tuned into epicentres of economic disaster. Houston and Dallas were the most notorious examples, but there were many other ones. Generalizing such events via computation of annual SDs, we can see quite new tendency. The curve on Fig. 1 is going down; in other words, inter-city gaps in banking achievements are reducing. Therefore, statistical materials of the 1980s enable us to suppose that there is an important double rule: under free-market competition and favourable economic conditions spatial stratification in the banking tends to increase, while during a crisis it decreases.

Before testing this rule on data derived from later periods, we must glance at the USSR of the 1980s. Throughout previous $50-55$ years the absolute state monopoly on credit activities meant the absolute geographical monopoly as well. The headquarters of closely tied stateowned banks were located only in Moscow. Other cities, depending on their administrative ranks, could have just hierarchically structured subdivisions. But at the middle of the 1980s general ineffectiveness of the Soviet economy became quite obvious even for ruling Communist elites. The time of great economic and political changes was coming.

Undoubtedly, the credit reform of 19871988 was one of the most important events of the period. Among some other innovations there 
were 'banking' clauses in the Law on Cooperation of 1988. Since then it was legally possible to establish private banks anywhere in the Soviet Union. Soon after that the largest of the Soviet Republics (i.e. the Russian Federation) fragmented its former centralized banks: the great majority of new, partly private corporations were created on the basis of long-existing regional branches. As a result, financial and geographical monopoly of Moscow was over. Although the capital city was the indisputable leader in the amount of emerging credit institutions, there were high concentrations of them in other cities, mainly in Leningrad (now St. Petersburg), Sverdlovsk (now Yekaterinburg) and Rostov-on-Don. Besides, in some other centres not so numerous, but rather large banks were created (in Chelyabinsk, Togliatti and especially in Ufa). In spite of all initial problems (for example, lack of adequate accounting rules and, consequently, lack of reliable statistics), Russia made its first steps to contemporary banking service.

Meanwhile the global crisis of 1990-1992 opened the second period (1990-2000) among those, which should be considered here.

For the American banking sector this recession was a prolongation of its own crisis that dated back to the mid-1980s. As before, the SDs on Fig. 1 continued to decline. But as soon as economic recovery started by the end of 1992 , the trend altered again. Moreover, the process of juridical liberalization was also recommenced, when the Riegle - Neal Interstate Banking and Branching Efficiency Act of 1994 at last permitted nation-wide corporative networks. This longawaited decision has prompted even more rapid stratification. Surely, the most advanced, effective and ambitious banking institutions now were able to enlarge their branching networks immensely. The central cities of such corporations have radically strengthened their domination over financial flows.
Amongst these booming places Charlotte was undoubtedly the most impressive example. As it was mentioned above, financial importance of the "Queen City" had been growing since the early 1980s. But the main breakthrough was made in 1998, when Charlotte-located NationsBank absorbed famous Bank of America of San Francisco. Due to the united corporation, that was also called the Bank of America, the North Carolinian city turned into the second largest banking centre in the USA, right after New York City. Besides Charlotte, there were some other winners, like Seattle in Washington, Cleveland in Ohio, Boston in Massachusetts, etc. On the other hand, there were numerous losers, including such prominent cities as Dallas in Texas and Phoenix in Arizona. Growing faster and faster, the first group raised the SDs curve on Fig. 1.

At the same decade post-Soviet Russia faced various (although mostly inevitable) difficulties of transition from the Communist "commanding system" to effective market economy. It was only in 1996-1997 that Russia's GDP started to grow. In 1998 this weak growth was interrupted by new crisis. Finally, since 1999 devaluation of rouble alongside with some other factors caused extraordinarily fast recovery.

In spite of these dramatic circumstances, banking was probably the most successful sector of the national economy (only the period of late 1998-1999 happened to be an exception). In a few years many of Russian credit companies have passed the way from badly organized "cooperatives" to advanced financial enterprises. It should be noted, however, that such result was closely tied with harsh filtrations: during 19951999 the number of banks fell from its peak at 2,500 to slightly over 1,300 .

Now, turning back to geography, we should primarily note that it was a period of triumph for Moscow. Earlier this enormous city partly delegated banking management to the rest of the 
country; now there was the opposite tendency. Moscow's share in the summarized assets of the national banking system was growing rapidly. Nonetheless, in post-Soviet Russia such trend was connected mainly with market factors, but not with administrative ones. Also, there was no danger of restoration of total monopoly: St. Petersburg, Ufa, Yekaterinburg and some other cities did not cease to be important banking nodes too. At the same time there were examples of dramatic downgrading, like Kemerovo that appeared to be one of the focal victims of the 1998-1999 crisis.

Regretfully, for the period prior to 1998 we have just annual rankings that include no more than 200 largest banks. However, even the available information enables us to suppose that there were enlarging gaps between booming and failing cities. Then, since 1998-1999 we can rely on large databases that embrace all Russian banks. Identical to the United States during their crises, in Russia we can see reducing SDs as a reflection of diminishing gaps (Fig. 1).

The third period (2001-2007) began with the global (and mainly American) recession of 2001. (For Russia it was already a time of growth, although temporally slowed). In the USA the above-mentioned double rule was proved for the third time already. Predictably enough, in 2001 there was a slight dropping of differences among cities, but since 2002 stratification was increasing again (Fig. 1). By that moment there was a new important factor in action: the Gramm - Leach Bliley Act of 1999 that demolished Rooseveltera barriers between traditional banking and stock market. Encouraged by new possibilities, American banks were expanding their operations and using new financial instruments.

Surely, management of such activities was getting more and more concentrated in the most successful cities. Membership of this group was rather stable. As before, it included New York,
Charlotte, San Francisco and some other financial metropolises. Wilmington in Delaware, Sioux Falls in South Dakota and Las Vegas in Nevada also should be mentioned here for their recognized roles in domestic off-shoring. Mighty banking cluster in Ohio (that is Columbus, Cincinnati and Cleveland) was also rising quite impressively at that period. Besides, this state became an important example of service transformations in the former "Rust Belt", which had been famous for its heavy industries many years ago. By contrast, neighbouring Michigan lost major part of its banking sector and spoiled that chance to make the local economy more diversified. Radically diverging paths of two "Rust Belt" states most clearly illustrated the degree of geographical stratifications in neoliberal economy.

Meanwhile the Russian banking industry was continuing its progress both in quantity and quality. Describing the second one, we must especially mention that in 2004 the long-expected mechanism of deposit insurance was launched. In its turn, this mechanism contributed immensely to further growth of the national credit sector.

As for spatial parameters of the banking, the basic tendencies now were quite close to American ones. For this period there are synchronically rising curves on Fig. 1, reflecting increase of geographical inequalities in two countries. Like in the USA, in Russia we can see, for example, dramatically diverging fates of cities that were traditionally famous for their heavy manufacturing: thus, Yekaterinburg and (to a lesser extent) Chelyabinsk became successful in financial services, while Volgograd, Omsk and even more obviously Kemerovo did not manage to take significant positions in banking. Alongside with Yekaterinburg, Kazan and Samara were also doing well during the whole period. On the contrary, Ufa that had been very important in the 1990s and early 2000s fell down in national rankings after 2004. Again, it was a 
vivid example of potential individual instabilities in economy of neoliberalism.

A short time later, the global crisis of 20082009 (which can be treated here as the beginning of the fourth, still continuing period) has caused repetition of the already depicted cycle. Now it was strongly pronounced and highly synchronized in both countries. During the recession there was striking downfall of the SDs, but under situation of recovery the curves skyrocketed again, especially in Russia (Fig. 1). Thus, the systems turned back to growing inter-city inequalities. Again, there were remarkable cases of downgrading (like Seattle in the USA and Kaliningrad in Russia) contrasting to breakthroughs of some other centres; surely, the prime contribution to growing gaps in their countries has been made by New York City and Moscow. In spite of all historic differences, American and Russian banking sectors gradually came to analogous regularities at least in the basic issue of stratification.

But alongside with such similarity, plentiful statistics of the 2000s - mid 2010s enable us to see some important distinctions between Russia and the United States. In the first case there is much higher concentration of financial resources in the leading node: Moscow's share in the national banking assets is more than $80 \%$, differing vastly from $30-35 \%$ that are controlled by New York in its country. Moreover, in the Russian banking sector administrative centres of oblasts and other regions usually predominate over subordinated territories, while analogous supremacy among capital cities of the U.S. states is quite rare (Fig. 2). In other words, until now administrative factors and geographical closeness to centres of budget policy have been much more important in Russia, than in the USA.

Also there is a great dissimilarity in location strategies of foreign corporations. In the USA commanding offices of such banks are represented in many cities and states, with especially high concentrations in New York City, New England states and California. In the Eastern Shore there are many branches of European credit institutions, while in the Pacific Shore Japanese business is notably active. In the Russian market (in spite of some juridical

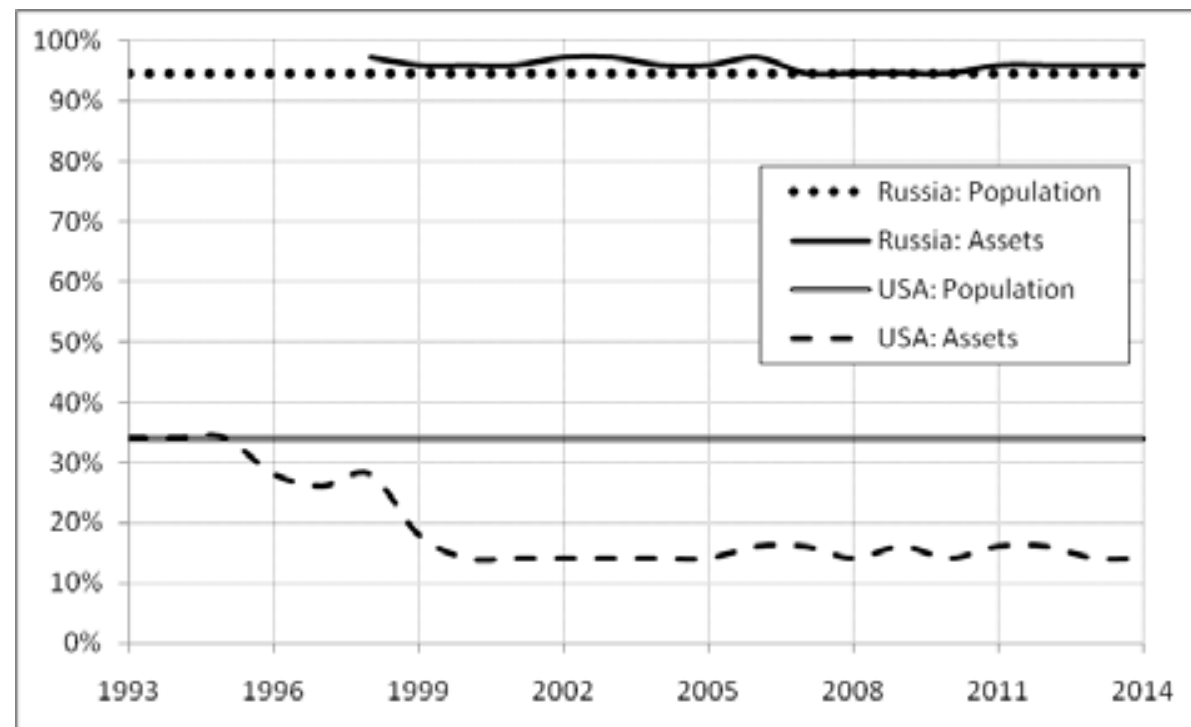

Fig. 2. Inner Constitutional Territories ${ }^{5}$ : Proportions of territories with administrative centres holding leadership in population numbers or banking assets. Calculations based on data from FDIC, FSGS, TsBRF and USCB 
restrictions) foreign banks are also quite energetic, especially French, Italian and Austrian ones. But headquarters of their subsidiaries are almost totally located in Moscow. At present there are just a few exceptions, like French Crédit Agricole and Danish Danske Bank in St. Petersburg. Thus, foreign banks in Russia are even more oriented to the capital city, in comparison with domestic corporations.

$$
* * *
$$

In conclusion, looking at banking landscapes of 2014-2015 and their previous evolution during three and a half decades, the author must note again that there is statistically proven double rule. In periods of economic growth geographical stratification usually intensifies, whereas in recessions tendency is opposite. During the following business cycle everything repeats again.
First calculated via SDs for the United States in the 1980s, this statistical regularity then appeared three more times in the same country. Besides, at least since the late 1990s it can be observed in Russia as well. It seems that such basic similarity is more important than the above-mentioned distinctions. How the considered rule will work in the years to come, whether it is applicable to other types of financial corporations, other countries or at the supranational level - all these are topics for further investigations.

\section{Acknowledgments}

I am using this opportunity to express my deep gratitude to Professor Bin Zhou (Southern Illinois University - Edwardsville, USA) for his pioneer studies, helpful advices and basic statistical information embracing series of early dates.

$1 \quad$ Banking geographies of the United States and Russian Federation were examined separately in several publications [Aubuchon \& Wheelock, 2010; Bernshtam \& Luzanov, 2001; DeYoung, Klier \& McMillen, 2004; Luzanov, 2002; Luzanov, 2009; Nikitin, 2012; Wheelock, 2011; Zhou, 1997; Zhou, 1998; Zhou, 2010], which are very important for understanding of the industry in focus. Nevertheless, there are many fundamental aspects that were not investigated before. This article is considered by its author as a new step because of enlarged and updated statistical basis that opens door to direct and standardized international comparisons.

2 It is necessary to note here that in the U.S. credit system individual banks are not as important as bank holding companies (BHCs). Each BHC controls one or more banks; sometimes the last ones are located very far from centres of their holdings. In this paper all measurements (in their American part) are based on data for BHCs.

3 Additionally, these two hundred American cities are grouped here into 131 Metropolitan and Micropolitan Statistical Areas (MSAs), according to official geographical standardizations by the U.S. Office of Management and Budget (OMS) [United States Office...].

4 Causes and course of the crisis (including its regional variations) later were considered in FDIC's study: [History...].

5 For the USA, the aggregate number of inner constitutional territories here is 50 (i.e. 50 states, while District of Columbia is excluded). In the case of Russia, the analogous amount here is 75. As for the beginning of 2014 there were 83 Subjects of the Federation (SF). This number was fluctuating slightly during post-Soviet years, but the above-mentioned date is optimal by the moment for statistical extrapolations and long-term retrospective observations. Additionally, eight SFs were excluded for various reasons: Moscow and St. Petersburg (as Federal Cities without directly subordinated areas), Moscow Oblast and Leningrad Oblast (since their administrative centres are located beyond the SFs) and Nenets AO, Jewish AO, Chukotka AO and Chechnya (SFs without local banks during the period under consideration).

\section{References}

Aubuchon, C.P. \& Wheelock, D.C. (2010). The Geographic Distribution and Characteristics of U.S. Bank Failures, 2007-2010: Do Bank Failures Still Reflect Local Economic Conditions? Federal Reserve Bank of St. Louis Review, 92(5), 395-415.

Bernshtam, E.S. \& Luzanov, A.N. Regional'nye Aspekty Organizatsii i Gosudarstvennogo Regulirovaniya Bankovskoi Sfery: Zaruberzhnyi i Rossiiskii Podkhody [Regional Aspects of Organization and Government Regulation in the Sphere of Banking: Foreign and Russian Approaches]. Moscow, Editorial URSS, 2001, 104 p. 
DeYoung, R., Klier, T. \& McMillen D.P. (2004). The Changing Geography of the U.S. Banking Industry. The Industrial Geographer, (2), 29-48.

Federal Deposit Insurance Corporation (FDIC). Institution Directory. Available at: https:// www2.fdic.gov/idasp/index.asp

Federal Reserve Archival System for Economic Research (FRASER). Economic Data. Available at: https://fraser.stlouisfed.org/data

Federal'naya Sluzhba Gosudarstvennoi Statistiki (FSGS) [Federal State Statistics Service]. Available at: http://www.gks.ru

History of the Eighties - Lessons for the Future. Vols. 1, 2. Available at: https://www.fdic.gov/ bank/historical/history/

Luzanov, A.N. Geografiia Bankovskoi Deyatel'nosti [Geography of Banking]. Moscow, MAKS Press, 2002, $252 \mathrm{p}$.

Luzanov, A.N. (2009). Bankovskaia Sistema SShA: Istoriia v Prostranstve [Banking System of the USA: a Spatial History]. Vestnik Moskovskogo Universiteta. Geografiia, (3), 11-15.

Nikitin, L.V. (2012). Bankovskoe Prostranstvo Rossii v 1988-2011 gg.: ot Monopolii Stolitsy k Konkurentsii Gorodov [Banking Area of Russia in 1988-2011: From Monopoly of the Capital to Competition of Cities]. Obshchestvennye nauki i sovremennost', (2), 5-20.

Tsentral'nyi Bank Rossiiskoi Federatsii (TsBRF). Spravochnik po Kreditnym Organizatsiyam [The Central Bank of Russian Federation. Credit Institutions Directory] Available at: http://www.cbr. ru/credit/main.asp

United Nations Statistics Division (UNSD). National Account Main Aggregates Database. Available at: http://unstats.un.org/unsd/snaama/dnlList.asp

United States Census Bureau (USCB). Available at: www.census.gov

United States Office of Management and Budget (OMB). Statistical Programs and Standards. Available at: https://www.whitehouse.gov/omb/inforeg_statpolicy\#ms

Wheelock, D.C. (2011). Banking Industry Consolidation and Market Structure: Impact of the Financial Crisis and Recession. Federal Reserve Bank of St. Louis Review, 93(6), 419-438.

Zhou, B. Banking Geography of the United States: Structure, Conduct, and Performance of Commercial Banks in the U.S. Metropolitan System. New York, Garland Publishing Inc., 1997, 251 p.

Zhou, B. (1998). Geographical Patterns of Interstate Banking: a Snapshot of the U.S. Metropolitan System in the early 1990s. Urban Geography, 19(1), 24-48.

Zhou, B. (2010). Changing Retail Banking Supply-Demand Mismatch: a Tale of Two States. International Journal of Applied Geospatial Research, 1(2), 207-228. 


\title{
Национальные банковские пространства в динамике \\ (на примерах США и России в 1980-е - 2015 гг.)
}

Л.В. Никитин

Челябинский государственный педагогический университет Россия, 454080, Челябинск, пр. Ленина, 69

\begin{abstract}
Подобно другим отраслям экономики банковская деятельность неравномерно распределена по странам и городам. Вместе с тем эта отрасль отличается доступностью больших статистических массивов, которые могут быть структурированы и обработаны в русле историко-географического исследования. Автор статьи рассматривает два важных примера конкуренции между городами: внутренние банковские пространства Соединенных Штатов Америки и Российской Федерачии. Проведенный количественный анализ, охватывающий серию из четырех макроэкономических иџилов, позволяет увидеть как общие процессы, так и различия между двумя странами.
\end{abstract}

Ключевые слова: города, банки, конкуренџия, США, Россия, неолиберальная экономика $1980-x-2010-x$ г2.

Научная специальность: 07.00.00 - исторические науки, 08.00.00 - экономические науки. 